\title{
De interpretatie van een testuitslag bij COVID-19
}

Michiel Bos

\begin{abstract}
De voorafkans op een SARS-CoV-2-infectie heeft belangrijke consequenties voor de interpretatie van testuitslagen. In periodes waarin de ziekte weinig voorkomt is een positieve test relatief onbetrouwbaar en in periodes waarin de ziekte veel voorkomt is een negatieve testuitslag relatief onbetrouwbaar.
\end{abstract}

De casussen beschrijven 4 mensen die allemaal positief testten op COVID-19. Toch hebben naar alle waarschijnlijkheid slechts 2 van de 4 daadwerkelijk COVID-19. Net als voor vrijwel alle medische tests geldt namelijk ook voor tests op COVID-19 dat de testuitslag niet 100\% betrouwbaar is. De uitslag kan fout-positief zijn (de patiënt test positief maar heeft in werkelijkheid geen COVID-19) en ook fout-negatief (de patiënt test negatief maar heeft in werkelijkheid wel COVID-19). Om een positieve testuitslag goed te kunnen interpreteren, heeft men de positief voorspellende waarde (PVW) nodig: de kans dat iemand die positief test de ziekte ook daadwerkelijk heeft. En om een negatief testresultaat goed te kunnen interpreteren, is de negatief voorspellende waarde (NVW) nodig: de kans dat iemand die negatief test de ziekte inderdaad niet heeft. Helaas zijn de PVW en de NVW van een test geen vaste waarden. Beide zijn in hoge mate afhankelijk van de voorafkans: de kans dat mensen die de test doen de ziekte ook daadwerkelijk

\begin{tabular}{|c|c|}
\hline \multicolumn{2}{|l|}{ BEGRIPPEN } \\
\hline Fout-positief & $\begin{array}{l}\text { De patiënt heeft de ziekte niet, maar de test is } \\
\text { positief }\end{array}$ \\
\hline Fout-negatief & $\begin{array}{l}\text { De patiënt heeft de ziekte wel, maar de test is } \\
\text { negatief }\end{array}$ \\
\hline $\begin{array}{l}\text { Positief voorspellende } \\
\text { waarde [PVW] }\end{array}$ & $\begin{array}{l}\text { De kans dat iemand met een positieve test de ziekte } \\
\text { echt heeft }\end{array}$ \\
\hline $\begin{array}{l}\text { Negatief voorspellende } \\
\text { waarde [NVW] }\end{array}$ & $\begin{array}{l}\text { De kans dat iemand met een negatieve test de ziekte } \\
\text { echt niet heeft }\end{array}$ \\
\hline Sensitiviteit & De kans dat iemand die de ziekte heeft positief test \\
\hline Specificiteit & $\begin{array}{l}\text { De kans dat iemand die de ziekte niet heeft negatief } \\
\text { test }\end{array}$ \\
\hline Voorafka & $\begin{array}{l}\text { De kans dat iemand die de test doet de ziekte heeft, } \\
\text { voordat de uitslag bekend is }\end{array}$ \\
\hline
\end{tabular}

\section{POSITIEVE TESTS}

\section{Een positieve PCR-test op 2 juli 2020}

Een 32-jarige vrouw bezoekt de GGD-teststraat omdat ze sinds een dag een droge hoest heeft en enigszins verkouden is. Een dag na haar bezoek krijgt ze de uitslag van de PCR-test: deze is positief.

\section{Een positieve PCR-test op 19 oktober 2020}

Een 52-jarige man bezoekt de GGD-teststraat omdat hij sinds een dag een droge hoest heeft en enigszins verkouden is. Een dag na zijn bezoek krijgt hij de uitslag van de test: deze is positief.

\section{Een positieve sneltest op 19 oktober 2020}

Een 52 -jarige huisarts heeft dienst op de huisartsenpost. Sinds een dag heeft hij een droge hoest en is hij enigszins verkouden. Om te bepalen of hij veilig kan werken, doet hij voorafgaand aan zijn dienst een antigeensneltest. Deze is positief.

\section{GEEN KLACHTEN MEER, MAAR NOG STEEDS POSITIEF}

Een huisarts heeft 2 weken geleden COVID-19 opgelopen. Hij heeft een droge hoest gehad en is enigszins verkouden geweest, maar intussen voelt hij zich weer de oude. Om er zeker van te zijn dat hij niet meer besmettelijk is, doet hij een PCR-test via de GGD. Deze is positief.

hebben. De voorafkans staat los van de eigenschappen van de test zelf, die meestal worden uitgedrukt in termen van sensitiviteit en specificiteit. Zie [kader Begrippen].

De voorafkans is het belangrijkste waaraan u moet denken voordat $u$ een testresultaat gaat interpreteren: hoe groot is de kans überhaupt dat de patiënt de ziekte bij zich draagt? Dat hangt bijvoorbeeld af van hoe kenmerkend de symptomen zijn en hoe vaak de ziekte voorkomt in de populatie waarin de test wordt uitgevoerd. Bij een pandemische infectieziekte zoals COVID-19 bepaalt de fase waarin de pandemie zich bevindt grotendeels de voorafkans. In de afgelopen zomer was COVID-19 in Nederland bijna geheel verdwenen en was de voorafkans bijna 0 , ook bij patiënten met kenmerkende klachten. In het najaar nam het aantal besmettingen enorm toe, en dus ook de voorafkans: bij bezoekers van de GGD-teststraat liep deze op tot ruim 20\%. Dit heeft grote consequenties voor de interpretatie van een positieve of negatieve testuitslag.

\section{PCR-, ANTIGEEN- EN ANTISTOFTESTS}

De meest gebruikte test voor COVID-19 is de reverse transcriptase-polymerasekettingreactie (RT-PCR) op viraal RNA verkregen uit de bovenste luchtweg. ${ }^{1}$ Bij COVID-19 piekt de 
hoeveelheid viraal RNA in de bovenste luchtweg kort na het begin van de symptomen. Na week 1 neemt de hoeveelheid RNA in de bovenste luchtweg af en vanaf week 4 is het daar bij de meeste patiënten niet meer aantoonbaar.

Naast de PCR-test bestaan er ook antigeensneltests. Deze hebben een vergelijkbaar werkingsprincipe als zwangerschapstests: ze meten of er viruseiwitten aanwezig zijn in de neus en/ of de keel. Ze zijn minder gevoelig dan PCR-tests.

Er zijn ook (snel)tests die in het bloed IgM- en IgG-antistoffen tegen COVID-19 kunnen detecteren. Deze tests worden doorgaans positief in week 2 na het begin van de symptomen. IgMantistoffen verdwijnen daarna weer binnen circa 7 weken, IgGantistoffen blijven meestal langer dan 7 weken aantoonbaar. ${ }^{1}$

\section{SENSITIVITEIT EN SPECIFICITEIT}

\section{De kans op een terecht positieve testuitslag}

De PCR-test identificeert lang niet alle COVID-19-patiënten. In een onderzoek bij patiënten die waren opgenomen met een op CT bevestigde COVID-19-pneumonie had slechts 70\% een positieve PCR-testuitslag. ${ }^{2}$ En in een onderzoek bij patiënten die waren opgenomen met een (uiteindelijk) met PCR bevestigde COVID-19-infectie was de eerste PCR-test positief bij slechts $88 \%$ (95\%-BI 82 tot 92$).{ }^{3}$ We zullen er voor dit artikel daarom van uitgaan dat de PCR-test een sensitiviteit heeft van $88 \%$. Dit is gebaseerd op statistisch heterogene onderzoeken van matige kwaliteit die werden uitgevoerd in ziekenhuizen. Schattingen over de sensitiviteit van antigeensneltests lopen sterk uiteen. In Nederland is de sensitiviteit van de meest gebruikte sneltest (PanBio ${ }^{\varpi}$ van Abbott) naar schatting 53-100\% ten opzichte van de PCR-test. ${ }^{4}$ Volgens nog niet gepubliceerde data van het LUMC heeft de PanBio ${ }^{\oplus}$-test op de huisartsenpost een sensitiviteit van 60\% (95\%-BI 42 tot $76 \%$ ).

\section{De kans op een terecht negatieve testuitslag}

In de literatuur schat men de specificiteit van de PCR-test op 96-99,2\%. ${ }^{5}$ Het zeer lage percentage positieve tests in de afgelopen zomer geeft aan dat er in die periode heel weinig fout-positieve uitslagen waren. Dit betekent dat de specificiteit van de PCR-test in die periode hoger moet zijn geweest dan 96-99,2\%: een schatting rond de 99,5\% lijkt gerechtvaardigd.

\section{Tabel 1}

Schatting van het aantal geteste personen in de week van 29 juni tot 5 juli 2020 dat daadwerkelijk COVID-19 had

\begin{tabular}{lrrrc} 
& \multicolumn{2}{c}{ Daadwerkelijk COVID-19 } & Totaal \\
& ja & nee & \\
\hline PCR positief & 40 & & \\
PCR negatief & 6 & 337 & $\mathbf{3 7 7}$ \\
Totaal & 46 & 66.981 & 66.987 \\
& & 67.318 & $\mathbf{6 7 . 3 6 4}$
\end{tabular}

De vetgedrukte getallen zijn gerapporteerd door het RIVM en de andere getallen zijn berekend, uitgaand van een sensitiviteit van $88 \%$ en een specificiteit van $99,5 \%$.

\section{DE KERN}

- De PCR-test voor COVID-19 kan, net als elke medische test, fout-negatief en fout-positief zijn.

- COVID-19 gaat in golven over de wereld en daardoor varieert de voorafkans dat iemand besmet is sterk. De positief en de negatief voorspellende waarde van een test veranderen mee, ongeacht de testeigenschappen.

- Als COVID-19 weinig voorkomt in de geteste populatie, is een negatieve testuitslag relatief betrouwbaar en een positieve testuitslag relatief onbetrouwbaar.

- Als COVID-19 veel voorkomt in de geteste populatie, is een positieve testuitslag relatief betrouwbaar en een negatieve testuitslag relatief onbetrouwbaar.

De kans dat iemand die géén COVID-19 had toch positief testte, is dan $0,5 \%$. De specificiteit van antigeentests ligt waarschijnlijk in dezelfde orde van grootte. ${ }^{4}$

In perioden waarin het virus veel voorkomt is de specificiteit van tests mogelijk lager. Er is een grotere kans dat een afgenomen monster gecontamineerd raakt en dat meer mensen positief blijven testen zonder dat ze nog besmettelijk zijn.

\section{INTERPRETATIE VAN DE TESTUITSLAGEN}

\section{Een positieve PCR-test op 2 juli 2020}

Tussen 29 juni en 5 juli 2020 bereikte het aantal besmettingen met COVID-19 het laagste peil in Nederland sinds het begin van de pandemie. In die week voerden de GGD's bijna 67.364 tests uit, waarvan er 377 (0,6\%) positief uitvielen. ${ }^{6}$ In [tabel 1] is berekend hoeveel uitslagen terecht positief, fout-positief, terecht negatief of fout-negatief moeten zijn geweest, uitgaand van een geschatte sensitiviteit van $88 \%$ en specificiteit van 99,5\%. Volgens die berekening waren 46 teststraatbezoekers daadwerkelijk besmet met COVID-19, onder wie slechts 40 van de 377 bezoekers met een positieve testuitslag. Voor iemand die in juli positief testte, was de PVW (de kans dat zij echt COVID-19 had) dus $40 / 377=11 \%$. De NVW (de kans dat iemand met een negatieve testuitslag inderdaad geen COVID-19 had) was daarentegen 66.981 / 66.987, oftewel bijna $100 \%$.

\section{Een positieve PCR-test op 19 oktober 2020}

Tussen 19 en 25 oktober 2020 viel de piek van de tweede besmettingsgolf in Nederland. In deze week voerden de GGD's ruim 321.363 tests uit, waarvan 59.092 (18\%) positief. ${ }^{6}$ De voorafkans dat een getest persoon daadwerkelijk COVID-19 had, was op 19 oktober dus veel groter dan op 2 juli. In [tabel 2] is de berekening van hierboven nogmaals uitgevoerd, met dezelfde sensitiviteit en specificiteit maar nu met de nieuwe cijfers. Van de 262.271 mensen die te horen kregen dat ze geen COVID-19 hadden, zouden er volgens de berekeningen 7.884 bij een herhaalde test positief zijn en van de 59.092 positief geteste bezoekers hadden er waarschijnlijk 57.814 daadwerkelijk COVID-19. De grote voorafkans heeft dus grote 
gevolgen voor de PWV en de NVW. De PVW was in oktober $57.814 / 59.092=98 \%$, vele malen hoger dan de $11 \%$ uit juli. De NVW was 254.387 / $262.271=97 \%$. Terwijl een negatieve test in de zomer de aanwezigheid van COVID-19 bijna uitsloot, had iemand met een negatieve test in oktober toch nog $3 \%$ kans om besmet te zijn.

\section{Een positieve sneltest op 19 oktober 2020}

Het is aannemelijk dat de huisarts die de sneltest deed dezelfde voorafkans had als de man in de voorgaande casus. De specificiteit van de sneltest is waarschijnlijk vergelijkbaar met die van de PCR-test en de PVW zal dus ook rond de 98\% liggen. Bij een negatieve testuitslag zou het verhaal anders geweest zijn, want de sneltest is veel minder sensitief (rond de 60\%) dan de PCR-test (88\%). Daardoor daalt de NVW van 97 naar 85\%, dus de kans dat iemand ondanks een negatieve sneltest toch COVID-19 heeft, is nog altijd 15\%.

Bedenk dat de kans op COVID-19 (dus ook bij een negatieve test) nog verder stijgt bij een grotere voorafkans, bijvoorbeeld als iemand ook nog koorts heeft of een huisgenoot met een aangetoonde infectie.

\section{Geen klachten meer, maar nog steeds positief}

De meeste patiënten blijven een aantal weken na COVID-19 positief bij een PCR-test; patiënten die ernstig ziek zijn geweest meestal langer dan patiënten die milde klachten hebben gehad. ${ }^{1}$ Een PCR-test toont de aanwezigheid van viraal RNA aan, maar niet of er voldoende levensvatbaar virus aanwezig is om besmettelijk te zijn. Alle beschikbare gegevens wijzen erop dat patiënten met milde of matige COVID-19 niet langer dan 10 dagen infectieus blijven, ook als ze na die tijd nog PCR-positief zijn. ${ }^{7}$ Patiënten met ernstige COVID-19 of met een ernstige immuunstoornis kunnen echter langer dan 10 dagen besmettelijk blijven. Het lijkt daarom gerechtvaardigd om de duur van de quarantaine te laten afhangen van de duur en ernst van de ziekte, en niet van PCR-testresultaten.

\section{BESCHOUWING}

Het is onjuist om er voetstoots van uit te gaan dat een positieve testuitslag de ziekte aantoont en een negatieve de ziekte

\section{Tabel 2}

Schatting van het aantal geteste personen in de week van 19 tot 25 oktober 2020 dat daadwerkelijk COVID-19 had

\begin{tabular}{lccc} 
& \multicolumn{2}{c}{ Daadwerkelijk COVID-19 } & Totaal \\
& Ja & Nee & \\
& & & \\
\hline PCR positief & 57.814 & 1278 & $\mathbf{5 9 . 0 9 2}$ \\
PCR negatief & 7884 & 254.387 & 262.271 \\
Totaal & 65.698 & 255.665 & $\mathbf{3 2 1 . 3 6 3}$
\end{tabular}

De vetgedrukte getallen zijn gerapporteerd door het RIVM en de andere getallen zijn berekend, uitgaand van een sensitiviteit van $88 \%$ en een specificiteit van $99,5 \%$. uitsluit. Bij het interpreteren van een testuitslag moet u bayesiaans denken: een positieve testuitslag maakt de aanwezigheid van de ziekte waarschijnlijker dan vóór de test, een negatieve testuitslag maakt de aanwezigheid van de ziekte minder waarschijnlijk dan vóór de test. Wanneer een aandoening weinig voorkomt en de patiënt ook nog een negatieve testuitslag krijgt, is het erg onwaarschijnlijk dat de patiënt de aandoening toch heeft. Anderzijds zullen veel patiënten met een positieve testuitslag de zeldzame ziekte toch niet hebben, zelfs wanneer de test een relatief hoge specificiteit heeft. Voor huisartsen zal dit geen verrassing zijn. Het is precies de reden dat we bij aspecifieke klachten terughoudend zijn om op allerlei zeldzame aandoeningen te testen.

Wanneer een ziekte echter veel voorkomt, zal een positieve testuitslag veel vaker kloppen. Een negatieve testuitslag dient in dit geval te worden gewantrouwd, zeker als de sensitiviteit van de test beperkt is.

COVID-19 is een pandemische infectieziekte die in golven over de wereld gaat en is daarom bij uitstek geschikt om te illustreren wat de voorafkans doet met een testuitslag. Iemand die positief testte in de zomer van 2020, toen er weinig infecties waren, had meestal geen COVID-19, maar iemand die eind oktober positief testte, toen er veel infecties waren, had bijna zeker wel COVID-19. En iemand die in de zomer negatief testte, had bijna 100\% zeker géén COVID-19, maar in oktober bood een negatieve test die garantie beslist niet.

\section{CONCLUSIE}

De PCR-test voor het aantonen of uitsluiten van COVID-19 zit er regelmatig naast. Van de mensen met een PCR-bevestigde infectie kreeg $12 \%$ in eerste instantie een negatieve testuitslag en van degenen die de ziekte niet hebben, testte $0,5 \%$ in eerste instantie positief. De voorafkans op COVID-19 heeft belangrijke consequenties voor de interpretatie van testuitslagen. In periodes waarin de ziekte weinig voorkomt is een positieve test relatief onbetrouwbaar, in periodes waarin de ziekte veel voorkomt is een negatieve testuitslag relatief onbetrouwbaar.

\section{LITERATUUR}

1. Sethuraman N, Jeremiah SS, Ryo A. Interpreting diagnostic tests for SARS-CoV-2. JAMA 2020;323:2249-51.

2. Ai T, Yang Z, Hou H, et al. Correlation of chest CT and RT-PCR testing for coronavirus disease 2019 (COVID-19) in China: A report of 1014 cases. Radiology 2020;296:E32-40.

3. Jarrom D, Elston L, Washington J, et al. Effectiveness of tests to detect the presence of SARS-CoV-2 virus, and antibodies to SARS-CoV-2, to inform COVID-19 diagnosis: a rapid systematic review. BMJ Evid Based Med 2020:bmjebm-2020-111511.

De volledige literatuurlijst staat bij dit artikel op www.henw.org.

Bos M. De interpretatie van een testuitslag bij COVID-19. Huisarts Wet 2021;64[5]:48-50. D0l:10.1007/s12445-021-1104-4.

Erasmus MC, Rotterdam: dr. M.J. Bos, huisarts-epidemioloog, docent Huisartsopleiding, m.j.bos.1@erasmusmc.nl.

Mogelijke belangenverstrengeling: niets aangegeven. 